\title{
Maternal and perinatal aspects of birth defects: a case-control study
}

\author{
Aspectos maternos e perinatais dos defeitos congênitos: um estudo caso-controle \\ Aspectos maternos y perinatales de los defectos congénitos: un estudio caso-control
}

Geiza César Nhoncanse ${ }^{1}$, Carla Maria R. Germano ${ }^{1}$, Lucimar Retto da S. de Avó1, Débora Gusmão Melo ${ }^{1}$

\section{ABSTRACT}

Objective: To assess the prevalence of congenital defects and to investigate their maternal and perinatal associated aspects by reviewing Birth Certificates.

Methods: Among all born alive infants from January 2003 to December 2007 in Maternidade da Santa Casa de Misericórdia of São Carlos, Southeast Brazil (12,199 infants), cases were identified as the newborns whose Birth Certificates registered any congenital defect. The same sex neonate born immediately after the case was chosen as a control. In total, 13 variables were analyzed: six were maternal related, three represented labor and delivery conditions and four were linked to fetal status. The chi-square and Fisher's exact tests were used to compare the variables, being significant $\mathrm{p}<0.05$.

Results: The prevalence of congenital defects was $0.38 \%$ and the association of two or more defects represented $32 \%$ of all cases. The number of mothers whose education level was equal or less than eight years was significantly higher among the group with birth defects $(p=0.047)$. A higher frequency of prematurity $(p<0.001)$ and cesarean delivery $(p=0.004)$ was observed among children with birth defects. This group also showed lower birth weight and Apgar scores in the $1^{\text {st }}$ and the $5^{\text {th }}$ minute $(p<0.001)$.

Conclusions: The prevalence of congenital defect of $0.38 \%$ is possibly due to underreporting. The defects notified in the Birth Certificates were only the most visible ones, regardless of their severity. There is a need of adequate

Instituição: Departamento de Medicina da Universidade Federal de São Carlos (UFSCar), São Carlos, SP, Brasil

1UFSCar, São Carlos, SP, Brasil epidemiological monitoring of birth defects in order to create and expand prevention and treatment programs.

Key-words: congenital abnormalities; epidemiological monitoring; primary prevention; perinatal care; maternal and child health.

\section{RESUMO}

Objetivo: Avaliar a prevalência de defeitos congênitos e investigar aspectos maternos e perinatais associados pela análise da Declaração de Nascido Vivo.

Métodos: Estudo do tipo caso-controle, considerando-se todos os nascidos vivos de janeiro de 2003 a dezembro de 2007 na Maternidade da Santa Casa de Misericórdia de São Carlos, o que totalizou 12.199 crianças. Identificaram-se como casos os recém-nascidos cuja Declaração de Nascido Vivo apontava algum defeito congênito. Para o grupo controle, escolheu-se a criança do mesmo sexo, nascida imediatamente após o caso. No total, analisaram-se 13 variáveis, sendo seis maternas, três relacionadas às condições de parto e quatro fetais. Os testes do qui-quadrado e exato de Fisher foram usados para comparar as variáveis, considerando-se nível de significância de 5\%.

Resultados: A prevalência de defeitos congênitos foi de $0,38 \%$, sendo que a associação de dois ou mais defeitos representou 32\% dos casos. No grupo com defeito congênito, houve um número maior de mães com escolaridade igual ou inferior a oito anos $(p=0,047)$. Entre as crianças com defeitos

Endereço para correspondência:

Débora Gusmão Melo

Rodovia Washington Luís (SP-310), km 235 - Campus da UFSCar

CEP 13565-905 - São Carlos/SP

E-mail: debora.gusmao@gmail.com,dgmelo@ufscar.br

Fonte financiadora: Fundação de Amparo à Pesquisa do Estado de São

Paulo (Fapesp), processo n²009/05417-1

Conflito de interesse: nada a declarar

Recebido em: 19/7/2013

Aprovado em: 15/10/2013 
congênitos, observou-se maior frequência de prematuridade $(p<0,001)$ e de parto cesáreo $(p=0,004)$, assim como peso e valores de Apgar no $1^{\circ}$ e $5^{\circ}$ minutos significativamente mais baixos $(p<0,001)$.

Conclusões: A prevalência de defeito congênito de $0,38 \%$ deve-se, possivelmente, à subnotificação das anomalias, tendo sido registrados os defeitos congênitos mais visíveis, independentemente da gravidade. Os dados deste trabalho reforçam a importância do monitoramento epidemiológico adequado, além da necessidade de criar e expandir programas de prevenção e tratamento de defeitos congênitos.

Palavras-chave: anormalidades congênitas; monitoramento epidemiológico; prevenção primária; assistência perinatal; saúde materno-infantil.

\section{RESUMEN}

Objetivo: Evaluar la prevalencia de defectos congénitos e investigar aspectos maternos y perinatales asociados por el análisis de la Declaración de Nacido Vivo.

Métodos: Estudio de tipo caso-control, teniendo en cuenta a todos los nacidos vivos desde enero de 2003 hasta diciembre de 2007, en la Maternidad de la Santa Casa de Misericórdia de São Carlos (São Paulo, Brasil), que totalizó 12.199 niños. Se identificaron como casos los recién nacidos cuya Declaración de Nacido Vivo señalaba algún defecto congénito. Para el grupo control, se eligió el niño del mismo sexo, nacido inmediatamente después del caso. En total, se analizaron 13 variables, siendo seis maternas, tres relacionadas a las condiciones de parto y cuatro fetales. Las pruebas del chi-cuadrado y exacto de Fisher fueron usadas para comparar las variables, considerándose un nivel de significancia de $5 \%$.

Resultados: La prevalencia de defectos congénitos fue del $0,38 \%$, siendo que la asociación de dos o más defectos representó el $32 \%$ de los casos. En el grupo con defecto congénito, hubo un número significativamente superior de madres con escolaridad igual o inferior a ocho años de estudio $(p=0,047)$. Entre los niños con defectos congénitos, se observó mayor frecuencia de prematuridad $(p<0,0001)$ y de parto cesáreo $(p=0,004)$, así como peso y valores de Apgar en el 1er y $5^{\circ}$ minutos significativamente inferiores $(p<0,0001)$.

Conclusiones: La prevalencia de defecto congénito del $0,38 \%$ se debe, posiblemente, a la subnotificación de las anomalías, habiendo sido registrados los defectos congénitos más visibles, independiente de la gravedad. Los datos de ese trabajo refuerzan la importancia de la monitoración epidemiológica adecuada, además de la necesidad de crear y expandir programas de prevención y tratamiento de defectos congénitos.

Palabras clave: anormalidades congénitas; monitoración epidemiológica; prevención primaria; asistencia perinatal; salud materno-infantil.

\section{Introduction}

Birth defects include all functional and structural anomalies arising from factors originating before birth, even when the abnormality is not apparent in the newborn, and is later recognized $^{(1,2)}$. From a biological standpoint, birth defects (BDs) represent a heterogeneous group of embryonic-fetal development disorders with distinct etiologic factors often involved simultaneously. The monogenic genetic or chromosomal conditions are responsible for $15-20 \%$ of cases. The multifactorial etiology, with polygenic genetic component associated with environmental factors, is implicated in another $20 \%$. Teratogens, especially congenital infections, and exposure to drugs, alcohol, and illicit drugs, are known to account for about $7 \%$ of BDs in $\mathrm{Brazil}^{(3)}$. The etiology of the disorder is unknown in about 50 to $60 \%$ of cases ${ }^{(3,4)}$.

The overall prevalence of BDs in Brazil does not differ from that found in other regions of the world and, generally, 2 to $5 \%$ of Brazilian newborns present some abnormality ${ }^{(1,5-7)}$. The anomalies may be single or multiple and, in clinical practice, the BDs are usually classified into minor, when the anomalies do not cause serious damage to the patient clinically or aesthetically, or major, when they result in anatomical, or functional changes, which can, often, lead to death ${ }^{(8)}$.

Birth defects are among the leading causes of mortality in areas with infant mortality rates below 15 per 1,000 , being responsible in this scenario, for about $30-50 \%$ of perinatal fetal deaths and $20 \%$ of neonatal deaths ${ }^{(9)}$. To the extent that there is better prenatal and perinatal care and greater control of infectious diseases, BDs become the leading cause of mortality during the first year of life ${ }^{(3,9)}$. This is the case in Brazil, where, since 2005, BDs and genetic conditions are the second leading cause of infant mortality in all regions of the country ${ }^{(10)}$. Furthermore, many children with BDs require more than one corrective surgery, causing hospitalizations and increased risk of clinical events. This reinforces the chronic aspect of BDs, which directly affects the quality of life of children and their families ${ }^{(11)}$.

This study was conducted with the aim to evaluate the prevalence of birth defects and to investigate maternal 
and perinatal associated aspects in a sample of newborns in the municipality of São Carlos, state of São Paulo, through the analysis of their Statements of Live Birth (SLB).

\section{Method}

The present study was a case-control study, conducted in the municipality of São Carlos and approved by the Research Ethics Committee on Human Research of Universidade Federal de São Carlos (UFSCar - opinion no 208/2009). Located in the geographic center of the state of São Paulo, the municipality has about 230,000 inhabitants $^{(12)}$ and a human development index of 0.805 , being considered the 14 th most developed municipality in the state ${ }^{(13)}$.

The research was based on data reported on the Statement of Live Birth, considering all live births in the Maternity of Santa Casa de Misericórdia de São Carlos, from January 1, 2003 to December 31st, 2007, totaling 12,199 children.

The Maternity of Santa Casa de Misericórdia in São Carlos has 34 beds for patients who use the Brazilian Unified Health System (SUS), three private beds, and 19 beds for the supplementary heath system. It has units for pregnant women under clinical treatment, antenatal and postnatal beds, rooming, obstetric center, nursery, and a human milk bank. It is linked to the Hospital of the same Santa Casa, which has a neonatal and an adult Intensive Care Unit (ICU), and performs high-complexity specialized services, being a reference for the municipalities within the region. It has an average of 250 births per month, which corresponds to about $80 \%$ of all births in the municipality of São Carlos.

The study considered as cases those live births whose SLB documented the presence of any kind of $\mathrm{BD}$, including newborns of any gestational age and weight, provided that a statement had been generated. For each case, a control was matched by choosing a child of the same sex, born immediately after.

In the context of the Maternity at Santa Casa de São Carlos, the SLB can be completed by any health professional involved in the care of the child, but is usually filled by a member of the nursing staff at the time of hospital discharge, after at least two physical exams: the first at birth and another with 24 hours of life.

In this study, while listing the types of BDs found, we considered the primary information contained on the SLB as they were recorded. These data were analyzed and grouped into three categories: recognized syndromes, association of two or more defects (reflecting situations of multiple defects, without a syndromic hypothesis), and single defects.

In total, we analyzed 13 variables: six maternal, four fetal, and three related to the conditions of the delivery. The maternal variables analyzed were: age, categorized as $\leq 9$ years, $20-34$ years, $35-39$ years, and $\geq 40$ years; education, categorized in up to 8 years and more than 8 years of study; occupation, categorized into inside or outside the home, marital status, categorized as with or without a partner; parity, categorized as first child, second child, third, or more children; and number of prenatal visits, categorized into one to three consultations, four to six consultations, and seven or more visits. The variables related to labor conditions were: type of pregnancy, categorized as single or multiple; gestational age, categorized as less than 32 weeks, 32-36 weeks, and 37 weeks or more; and type of delivery, categorized as vaginal or cesarean. The studied fetal variables were gender, categorized as feminine, masculine, and not defined; weight, categorized as $<1500 \mathrm{~g}, 1501-2499 \mathrm{~g}$, and $\geq 2500$ g; and Apgar score at 1 and 5 minutes, rated in four categories $(8-10 ; 7 ; 4-6 ; 0-3)$.

The statistical analysis was conducted with GraphPad Prism software, version 4.0. There were descriptive statistics of the data and the chi-square and Fisher exact test for comparison of variables, according to the number of categories of each variable analyzed, establishing significance at $5 \%$.

\section{Results}

Among the 12,199 live births, 47 cases with some kind of $\mathrm{BD}$ were identified by the analysis of the SLB, representing a prevalence of $0.38 \%$. The combination of two or more defects was observed in $32 \%$ of all cases, the presence of known syndromes in $6 \%$, and the presence of isolated anomalies in $62 \%$, with a prevalence of cardiovascular disorders, and the central nervous system (Table 1).

Regarding maternal variables (Table 2), we found a higher number of mothers with education $\leq 8$ years in the group with $\mathrm{BD}(p=0.047)$. As for variables related to the delivery conditions (Table 2), there were differences in the frequency distribution data regarding gestational age and type of delivery, and, in children with $\mathrm{BD}$, there was a higher percentage of prematurity $(p<0.0001)$ and cesarean section $(p=0.004)$. Regarding fetal variables (Table 3 ), children with BD were born with significantly lower $(p<0.0001)$ Apgar scores at 1 and 5 minutes and lower birth weights compared to children in the control group. 
Table 1 - Types of birth defects recorded in the Statement of Live Birth

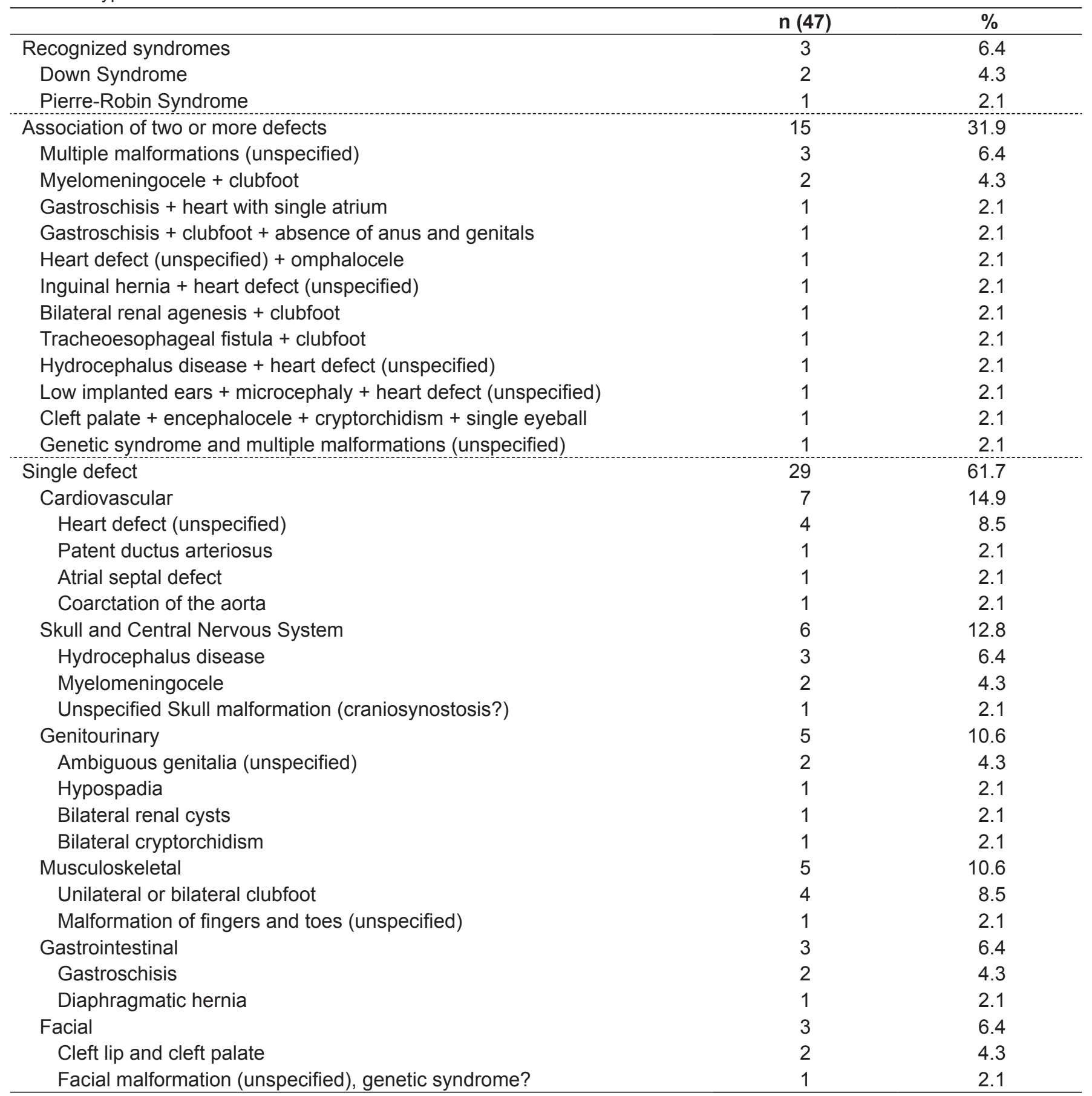

\section{Discussion}

The SLB is a document standardized by the Brazilian Ministry of Health, that should be completed in all the national territory, for all children born in health facilities or at home, being essential for the registration in a civil registry office. It is used as a document for the entry on the System of
Information of Live Births (Sinasc). Since 2000, with the aim to monitor the prevalence of BDs, there is a specific field on the SLB to register and describe the observed anomalies ${ }^{(14)}$. However, despite the efforts of the Ministry of Health, there is still underreporting regarding BDs in Brazil.

A survey conducted in 2001 in the municipality of São José dos Campos, state of São Paulo, with data on 9,341 
Table 2 - Distribution of maternal and delivery variables among newborns with birth defects (cases) and controls

\begin{tabular}{|c|c|c|c|c|c|c|}
\hline & & \multicolumn{2}{|c|}{ Cases $(n=47)$} & \multicolumn{2}{|c|}{ Controls (n=47) } & \multirow{2}{*}{$p$-value } \\
\hline & & $\mathbf{n}$ & $\%$ & $\mathbf{n}$ & $\%$ & \\
\hline \multirow{28}{*}{ 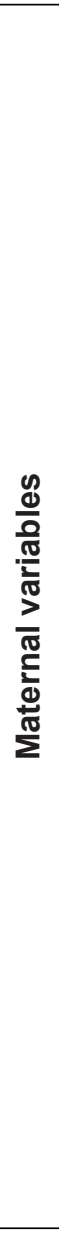 } & Age & & & & & \multirow{6}{*}{ NS } \\
\hline & $\leq 19$ & 8 & 17.0 & 7 & 14.9 & \\
\hline & 20 to 34 & 31 & 66.0 & 33 & 70.2 & \\
\hline & 35 to 39 & 4 & 8.5 & 7 & 14.9 & \\
\hline & $\geq 40$ & 3 & 6.4 & - & - & \\
\hline & Without information & 1 & 2.1 & - & - & \\
\hline & \multicolumn{5}{|l|}{ Education } & \multirow{4}{*}{0.047} \\
\hline & $\leq 8$ & 20 & 42.5 & 11 & 23.4 & \\
\hline & $>8$ years & 25 & 53.2 & 36 & 76.6 & \\
\hline & No information & 2 & 4.3 & - & - & \\
\hline & Occupation & & & & & \multirow{4}{*}{ NS } \\
\hline & Housewife & 35 & 74.5 & 38 & 80.9 & \\
\hline & Work outside the house & 8 & 17.0 & 9 & 19.1 & \\
\hline & No information & 4 & 8.5 & - & - & \\
\hline & Marital status & & & & & \multirow{4}{*}{ NS } \\
\hline & With Partner & 23 & 48.9 & 23 & 48.9 & \\
\hline & No partner & 17 & 36.2 & 22 & 46.8 & \\
\hline & No information & 7 & 14.9 & 2 & 4.3 & \\
\hline & \multicolumn{5}{|l|}{ Parity } & \multirow{5}{*}{ NS } \\
\hline & First child & 16 & 34.0 & 19 & 40.4 & \\
\hline & Second child & 30 & 63.9 & 27 & 57.5 & \\
\hline & Three or more children & 0 & - & 1 & 2.1 & \\
\hline & No information & 1 & 2.1 & - & - & \\
\hline & \multicolumn{5}{|c|}{ Number of prenatal consultations } & \multirow{5}{*}{ NS } \\
\hline & 1 to 3 & 5 & 10.6 & 1 & 2.1 & \\
\hline & 4 to 6 & 7 & 14.9 & 6 & 12.8 & \\
\hline & $\geq 7$ & 25 & 53.2 & 38 & 80.9 & \\
\hline & No information & 10 & 21.3 & 2 & 4.3 & \\
\hline \multirow{10}{*}{ 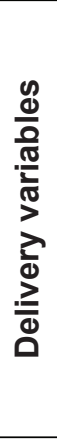 } & Type of delivery & & & & & \multirow[b]{3}{*}{ NS } \\
\hline & Single & 43 & 91.5 & 47 & 100 & \\
\hline & Multiple & 4 & 8.5 & - & - & \\
\hline & Gestational age & & & & & \multirow{4}{*}{$<0.0001$} \\
\hline & $<32$ weeks & 11 & 23.4 & - & - & \\
\hline & 32 a 36 weeks & 20 & 42.5 & 2 & 4.3 & \\
\hline & $\geq 37$ weeks & 16 & 34.0 & 45 & 95.7 & \\
\hline & \multicolumn{5}{|l|}{ Type of delivery } & \multirow{3}{*}{0.004} \\
\hline & Vaginal & 9 & 19.1 & 23 & 48.9 & \\
\hline & Cesarean & 38 & 80.9 & 24 & 51.1 & \\
\hline
\end{tabular}

NS: no significant

births from the SLB showed a prevalence of BDs of $0.88 \%{ }^{(15)}$. A study conducted in the Paraíba Valley with 41,838 live births between 2002 and 2003 showed that the field corresponding to the BDs was blank in $1.5 \%$ of SLB and the prevalence of abnormalities recorded was of $0.76 \%{ }^{(16)}$. In the municipality of Rio de Janeiro, based on the SLB, the prevalence of BDs was of $0.83 \%{ }^{(17)}$ between 2000 and 2004.
One important aspect of monitoring BDs is that stillbirths, which have a high prevalence of genetic conditions and severe congenital anomalies, are not included in Sinasc, being registered in the Mortality Information System (SIM). In the municipality of Vitória, state of Espírito Santo, the crossing of information from Sinasc and SIM revealed an occurrence of BDs in $0.4 \%$ of live 
Table 3 - Distribution of fetal variables in newborns with birth defects (cases) and their controls

\begin{tabular}{|c|c|c|c|c|c|}
\hline \multirow[t]{2}{*}{ Fetal variables } & \multicolumn{2}{|c|}{$\begin{array}{l}\text { Cases } \\
(n=47)\end{array}$} & \multicolumn{2}{|c|}{$\begin{array}{c}\text { Controls } \\
(n=47)\end{array}$} & \multirow[t]{2}{*}{$p$-value } \\
\hline & $\mathrm{n}$ & $\%$ & $\mathbf{n}$ & $\%$ & \\
\hline \multicolumn{6}{|l|}{ Sex } \\
\hline Female & 22 & 46.8 & 22 & 46.8 & \\
\hline Male & 23 & 48.9 & 25 & 53.2 & NS \\
\hline Undefined & 2 & 4.3 & - & - & \\
\hline \multicolumn{6}{|l|}{ Weight } \\
\hline$<1,500 \mathrm{~g}$ & 13 & 27.7 & - & - & \\
\hline 1,501 to $2,499 \mathrm{~g}$ & 22 & 46.8 & 4 & 8.5 & $<0.0001$ \\
\hline$\geq 2,500 \mathrm{~g}$ & 12 & 25.5 & 43 & 91.5 & \\
\hline \multicolumn{6}{|l|}{ APGAR 1st minute } \\
\hline 8 to 10 & 4 & 8.5 & 37 & 78.7 & \\
\hline 7 & 4 & 8.5 & 7 & 14.9 & \\
\hline 4 to 6 & 13 & 27.7 & 2 & 4.3 & $<0.0001$ \\
\hline 0 to 3 & 22 & 46.8 & - & - & \\
\hline No information & 4 & 8.5 & 1 & 2.1 & \\
\hline \multicolumn{6}{|l|}{ APGAR 5th minute } \\
\hline 8 to 10 & 16 & 34.0 & 46 & 97.9 & \\
\hline 7 & 1 & 2.1 & - & - & \\
\hline 4 to 6 & 16 & 34.0 & - & - & $<0.0001$ \\
\hline 0 to 3 & 10 & 21.3 & - & - & \\
\hline No information & 4 & 8.5 & 1 & 2.1 & \\
\hline
\end{tabular}

NS: no significant

births and of 5.5\% in stillbirths from January 2001 to December $2004^{(4)}$.

The prevalence of $\mathrm{BDs}$ of $0.38 \%$ recorded in this study, is possibly a result of underreporting and reflects the frailty of Sinasc as a system to monitor and survey BDs. It is important to consider that although the SLB is population-based, this survey is hospital-based, since we did not investigate the totality of births in the municipality. Nevertheless, since the Maternity of Santa Casa accounts for $80 \%$ of all births in the municipality and is a reference for assistance in the region, it is estimated that most children with BDs was born at this health facility and did not have his or her anomaly identified and described on the SLB.

The monitoring of BDs is more effective when the information is collected directly from the infant's medical record and not from the SLB. A sectional study, conducted in the municipality of Rio de Janeiro, with a sample of 9,386 births, from 1999 to 2001, through interviews with mothers immediately after birth and analysis of medical records, detected a prevalence of $\mathrm{BDs}$ of $1.7 \%{ }^{(18)}$. In Ribeirão Preto, state of São Paulo, a research performed at the Maternity of Santa Casa de Misericórdia, comparing the information on the SLB and the medical records of 6,418 live births between 2000 and 2004, confirmed the underreporting of BDs on the SLB ${ }^{(7)}$. In Recife, state of Pernambuco, a prospective study from September 2004 to May 2005, with analysis of all the 4,043 deliveries at Instituto Materno Infantil Prof. Fernando Figueira, collecting data directly from the newborns' medical records and clinical examinations, determined a frequency of BDs of $2.7 \%$ in live births and $6.7 \%$ in stillbirths ${ }^{(19)}$. In the municipality of São Carlos, a descriptive study comparing information from medical records, death certificates, and SLBs demonstrated errors of accuracy and precision related mainly to the transcription of the anomaly from the medical records to the SLB, the codification, and data feeding on Sinasc, which compromised the reliability of the SLB as a source of information on $\mathrm{BDs}^{(6)}$.

A study conducted in Campinas, in 2004, with 2,843 live births, with 92 cases of birth defects, compared the information of the Sinasc database with information from the Latin American Collaborative Study on Congenital Malformations, observing underreporting of $46.8 \%$ for all cases of $\mathrm{BD}$ and $36.4 \%$ when the analysis was restricted to major $\mathrm{BDs}^{(20)}$, suggesting that minor anomalies are hardly recognized or are neglected during the filling of the SLB. Many minor BDs are dysmorphias, i.e., normal variants of the phenotype without clinical relevance, although they may indicate general changes in morphogenesis and eventually serve as a diagnostic clue for severe BDs or even malformation syndromes ${ }^{(8)}$. In fact, $90 \%$ of infants with three or more minor BDs present a major BD, and minor BDs often occur in malformation syndromes; $43 \%$ of patients with idiopathic intellectual disability present three or more BDs, of which $80 \%$ are minor ${ }^{(8)}$.

As for the types of BD found in this study, $32 \%$ of cases are represented by situations in which there are two or more minor and major defects, suggesting genetic syndromes. Generally, our findings were similar to those described by other authors ${ }^{(20-22)}$ : The information recorded on the SLB is related to the cases of visible BDs, more easily detected, regardless of severity. The results of this study reflect the way the SLB is filled. The declaration may be issued by any healthcare professional responsible for assistance during the delivery or care of newborns, i.e., physicians, nurses, and technical professionals. Naturally, the level of knowledge and the level of training of these professionals in recognizing morphological defects are quite different. Moreover, when 
any $\mathrm{BDs}$ are identified, there is no standardized protocol on how they should be registered. A set of BDs may be described separately as combined BDs but may also be characterized as a known genetic syndrome. This procedure is at the discretion of the professional responsible for filling, in a quite subjective manner. Another aspect that influences the completion of the SLB is the availability of resources for the diagnosis of BD. In this study, even though the Maternity is a reference center for high-complexity perinatal care and has resources for further diagnosis, we observed that many BDs were recorded in unspecific terms, such as "congenital heart disease " or "multiple malformations".

Training courses for professionals involved in the task of filling the SLB and the preparation of manuals to guide the correct completion of the field related to anomalies are initiatives that can help to reduce the underreporting of $\mathrm{BDs}$, as demonstrated by the experience in four hospitals in the municipality of São Paulo, involving 10,000 births ${ }^{(23)}$. In this study, during the year 2008, there was an increased reporting of BDs in the four maternities after the establishment of a virtual network support, allowing that cases with suspected anomalies were assessed at distance by specialists from a center of excellence in medical genetics ${ }^{(23)}$.

After the correct identification of the BD and its proper registration on the SLB, it is equally important to know the procedure and to control the flow of information within the Sinasc. A copy of the SLB is collected by the Municipal Health Secretariat, which should encode and record information, which will be passed on to state and federal agencies. For Sinasc to be a reliable source of data, it is necessary to ensure the proper coding of $\mathrm{BDs}$, the record, and the possibility of recapturing information when needed. Data from this study reinforce the need to improve the system, especially in relation to the procedures used in the maternities to capture, record, and transmit information about BDs. With guidance on the importance and functioning of the SLB, the Sinasc may become an excellent database on BDs, allowing municipalities to plan an appropriate care for the children, to assess their needs and their families' needs, and to create a prevention program to the various etiologies.

To prevent birth defects, action is needed in health education, particularly regarding exposure to teratogens such as alcohol, tobacco, and illicit drugs. In the present study, we observed lower education among mothers of children with $\mathrm{BD}$, consistent with other studies ${ }^{(18,24-26)}$. It is likely that the low educational level is responsible for increased exposure to teratogens, due to the poor level of knowledge of the risks involved.
A case-control study conducted in 2009 in the municipality of Petrolina, state of Pernambuco, with 42 children with $\mathrm{BD}$, showed an association between low education, exposure to pesticides during pregnancy, and the presence of $\mathrm{BDs}^{(24)}$. In the study by Costa et al, conducted in the municipality of Rio de Janeiro, with 9,386 puerperal women, education $\leq 7$ years was a risk factor for the presence of $\mathrm{BDs}^{(18)}$. In general, the existence of an association between the education level and the social class is accepted. Low socioeconomic status also contributes to the prevalence of BDs. A research conducted in Porto Alegre, state of Rio Grande do Sul, with 275 lowincome pregnant women and 137 middle-class women, demonstrated 6 other risk factors for BDs significantly increased in low-income situations: frequency of adolescent pregnancies, self-medication, smoking, unplanned pregnancies, unwanted pregnancies, and abortion attempts ${ }^{(3)}$. Other risk factors for BDs include pregnancy over 35 years, consanguineous marriages, and previous family history of anomalies.

In this study, other maternal variables such as age, occupation, marital status, and number of prenatal consultations showed no statistical difference between cases and controls. On the other hand, in the study by Costa $e t$ al, congenital anomalies were significantly associated with inadequate prenatal care, with up to three visits during the prenatal period ${ }^{(18)}$.

As for perinatal care, it is known that the conditions for the birth of a newborn with BDs are directly associated with a worse prognosis and we cannot disregard the possibility that major anomalies cooperate with complications in this period. In the present study, there was a higher frequency of prematurity and cesarean section in children with BDs, what is in agreement with other studies ${ }^{(15,16,19,27)}$. In the study by Amorim et al, performed in a maternity-school treating high-risk pregnancies, about $55 \%$ of newborns with BDs were premature versus $33 \%$ of newborns without anomalies ${ }^{(19)}$. In this research, $66 \%$ of cases were born with less than 36 weeks of gestational age, while in the children without BDs the rate of prematurity was $4 \%(19)$. In a study conducted in the municipality of Caxias do Sul, Rio Grande do Sul, from 1998 to 2007, involving 14,351 births, the cesarean-section was significantly associated to the presence of $\mathrm{BDs}^{(27)}$. It should be highlighted, however, the fact that certain defects, such as bulky hydrocephalus and all anomalies in which there is risk of rupture of membranes (e.g., meningomyelocele and omphalocele), represent formal indication for cesarean, which may justify this kind of delivery preference for the children with BD.

Although multiple births, especially monozygotic, are associated to $\mathrm{BDs}^{(8)}$, in the present study there were no 
differences in the distribution of single and multiple pregnancies among children with or without $\mathrm{BD}$, which may have occurred due to the small number of multiple pregnancies. The distribution of the infant's sex was not different either, which is consistent with other studies ${ }^{(4,16,19)}$.

In line with the literature ${ }^{(15,16,19,27)}$ and agreeing with the highest incidence of prematurity, data from this study showed low birth weight and lower Apgar scores at 1 and 5 minutes in children with BDs, which contributed to infant morbidity and mortality, especially in the perinatal and neonatal periods. A survey conducted in the state of Pernambuco with data obtained from the Mortality Information System for the years 1993-2003 showed an increasing trend of the coefficients of perinatal, early neonatal, total neonatal, and child mortality by
$\mathrm{BDs}^{(28)}$. In the study by Amorim et al, BDs represented $24 \%$ of early neonatal deaths and $26 \%$ of total neonatal deaths ${ }^{(19)}$.

Data from this study reinforce the importance of adequate epidemiological monitoring, besides the need to create and expand programs for the prevention and treatment of birth defects. These measures, coupled with adequate assistance in perinatal and neonatal periods, may help reduce child mortality in Brazil.

\section{Acknowledgements}

We are thankful to the Foundation of Research Support of the State of São Paulo (Fapesp), for the financial support to G.C. Nhoncanse (case number no 2009/05417-1).

\section{References}

1. Horovitz DD, Llerena Jr JC, Mattos RA. Birth defects and health strategies in Brazil: an overview. Cad Saude Publica 2005;21:1055-64.

2. Hook EB. Incidence and prevalence as measures of the frequency of birth defects. Am J Epidemiol 1982;116:743-7.

3. Schüler-Faccini L, Leite JC, Sanseverino MT, Peres RM. Evaluation of potential teratogens in Brazilian population. Cienc Saude Coletiva 2002;7:65-71.

4. Maciel EL, Gonçalves EP, Alvarenga VA, Polone CT, Ramos MC. Epidemiological profile of congenital malformations in Vitória, Espirito Santo, Brazil. Cad Saude Colet 2006;14:507-18.

5. International Centre for Birth Defects of the International Clearinghouse for Birth Defects Monitoring Systems [homepage on the Internet]. World atlas for birth defects - 2003. $2^{\text {nd }}$ ed. [cited 2013 Sep 17]. Available from: http://www. who.int/genomics/publications/reports/en

6. Nhoncanse GC, Melo DG. Reliability of birth certificates as a source of information on congenital defects in the city of São Carlos, São Paulo, Brazil. Cienc Saude Coletiva 2012;17:955-63.

7. Righetto AL, Huber J, Machado JC, Melo DG. Congenital abnormalities: validation of birth certificates in a maternity of Ribeirão Preto, São Paulo. Pediatria (São Paulo) 2008;30:159-64.

8. Jones KL. Smith's recognizable patterns of human malformation. $6^{\text {th }}$ ed. Philadelphia: Elsevier Saunders; 2006.

9. Gomes MR, Costa JS. Infant mortality and congenital abnormalities in the Municipality of Pelotas, state of Rio Grande do Sul, Brazil: ecologic study in the period 1996-2008. Epidemiol Serv Saude 2012;21:119-28.

10. Brasil - Ministério da Saúde - DATASUS [homepage on the Internet]. Estatísticas Vitais: mortalidade e nascidos Vivos - 1994-2011 [cited 2013 May 7]. Available from: http://www2.datasus.gov.br/DATASUS/index.php?area=0205\&VObj=http:// tabnet.datasus.gov.br/cgi/deftohtm.exe?sinasc/cnv/nv

11. Polita NB, Ferrari RA, Moraes PS, Sant'Anna FL, Tacla MT. Congenital anomalies: hospitalization in a pediatric unit. Rev Paul Pediatr 2013;31:205-10.

12. Brasil - Instituto Brasileiro de Geografia e Estatística [homepage on the Internet]. Censo Demográfico 2010 [cited 2013 May 7]. Available from: http:// cidades.ibge.gov.br/xtras/perfil.php?lang=\&codmun $=354890$

13. Brasil - Programa das Nações Unidas para o Desenvolvimento do Brasil [homepage on the Internet]. Atlas do Desenvolvimento Humano no Brasil 2002 [cited 2013 May 7]. Available from: http://atlasbrasil.org.br/2013/perfil/ sao-carlos_sp

14. Brasil - Ministério da Saúde; Fundação Nacional de Saúde. Manual de Instruções para o preenchimento da Declaração de Nascido Vivo. Brasília: Ministério da Saúde/Funasa; 2009.
15. Nascimento LF, Pinto CO, Proença FP, Gotlieb SL. Prevalence of congenital abnormalities in São José dos Campos, São Paulo, Brazil, in 2001. Rev Paul Pediatr 2006;24:47-51.

16. Pinto CO, Nascimento LF. Prevalence study of birth defects in Vale do Paraíba, São Paulo, Brazil. Rev Paul Pediatr 2007;25:233-9.

17. Guerra FA, Llerena Jr JC, Gama SG, Cunha CB, Theme Filha MM. Birth defects in Rio de Janeiro, Brazil: an evaluation through birth certificates (2000-2004). Cad Saude Publica 2008;24:140-9.

18. Costa CM, Gama SG, Leal MC. Congenital malformations in Rio de Janeiro, Brazil: prevalence and associated factors. Cad Saude Publica 2006;22:2423-31.

19. Amorim MM, Vilela PC, Santos AR, Lima AL, Melo EF, Bernardes HF et al. Impact of congenital malformations on perinatal and neonatal mortality in an university maternity hospital in Recife. Rev Bras Saude Mater Infant 2006;6 (Suppl 1):s19-s25.

20. Luquetti DV, Koifman RJ. Quality of reporting on birth defects in birth certificates: case study from a Brazilian reference hospital. Cad Saude Publica 2009;25:1721-31

21. Wang Y, Druschel CM, Cross PK, Hwang SA, Gensburg LJ. Problems in using birth certificate files in the capture-recapture model to estimate the completeness of case ascertainment in a population-based birth defects registry in New York State. Birth Defects Res A Clin Mol Teratol 2006;76:772-7.

22. Guerra FA, Llerena Jr JC, Gama SG, Cunha CB, Theme Filha MM. Reliability of birth defect data on birth certificates of Rio de Janeiro, Brazil, 2004. Cad Saude Publica 2008;24:438-46.

23. De Nicola PD, Cernach MC, Perez AB, Brunoni D. Use of the Internet to report congenital malformations on birth certificates at four public maternity hospitals in the city of São Paulo, Brazil. Cad Saude Publica 2010;26:1383-90.

24. Silva SR, Martins JL, Seixas S, Silva DC, Lemos SP, Lemos PV. Congenital defects and exposure to pesticides in São Francisco Valley. Rev Bras Ginecol Obstet 2011;33:20-6.

25. Brender JD, Felkner M, Suarez L, Canfield MA, Henry JP. Maternal pesticide exposure and neural tube defects in Mexican Americans. Ann Epidemiol 2010;20:16-22.

26. Waller SA, Paul K, Peterson SE, Hitti JE. Agricultural-related chemical exposures, season of conception, and risk of gastroschisis in Washington State. Am J Obstet Gynecol 2010;202:241.e1-6.

27. Calone A, Madi JM, Araújo BF, Zatti H, Madi SR, Lorencetti J et al. Congenital defects: maternal and perinatal features. Rev AMRIGS 2009;53:226-30.

28. Arruda TA, Amorim MM, Souza AS. Mortalidade determinada por anomalias congênitas em Pernambuco, Brasil, de 1993 a 2003. Rev Assoc Med Bras 2008:54:122-6. 